\title{
The Impact of Tropospheric Planetary Wave Variability on Stratospheric Ozone.
}

Principal Investigator: Michael B. McElroy

Co-Investigator: Hans R. Schneider

DoE Grant DE-FG02-98ER62585

Final report.

The goal of our project was to improve our understanding of the role of the stratosphere in inducing long term variations of the chemical composition of the troposphere. Changes in stratospheric transport occur on decadel timescales in response to changes in the structure of planetary wave patterns, forced in the troposphere. For many important tracers, such as column amounts of ozone, this variability of the transport leads to changes with signatures very similar to those induced by anthropogenic releases of chemicals into the atmosphere.

Air enters the stratosphere at the tropical tropopause. Part of this air is transported fairly quickly (on a timescale of less than a year) to midlatitudes and recirculated back into the troposphere. The remaining air is lofted to high altitudes in the tropics and returned in the downward branch of the Brewer-Dobson circulation after about 5 years. Measurements of long lived tracers in recent years have shown that these two branches of the circulation are fairly distinct. The outflow of air from tropics to midlatitudes occurs predominantly at low and at high stratospheric altitudes. It is reduced significantly in the altitude region between approximately 18 and $30 \mathrm{~km}$.

Both two- and three-dimensional models have difficulties in accurately representing the two branches of the stratospheric circulation and, therefore, tracer gradients in the lower stratosphere. Over the course of this project, we developed a new interactive two-dimensional model of the dynamics, chemistry and radiation of the stratosphere. The meridional circulation of the stratosphere is driven by dissipating Rossby waves and small scale gravity waves. In our model, the Rossby wave forcing is parameterized following the residual circulation theory as consistently as possible. Gravity wave forcing is implemented as a simple Rayleigh drag.

The model has been used to interpret available data of tracers. Particular emphasis has been placed on long lived tracers in the lower stratosphere because those are most sensitive to the description of dynamics and transport in a model. We found that a fairly coherent picture of tracer distributions is obtained when a layer of reduced gravity wave drag is assumed for the lower stratosphere. This assumption, combined with the use of the nonlinear momentum advection terms in the zonal mean wind equation allows not only for the interpretation of long term annual means, but also variability observed on seasonal time scales and tracer fluctuations associated with the quasi-biennial oscillation (QBO). The effects of gravity waves are parameterized as subgrid scale processes in all atmospheric models. Our results suggest that the power of models to predict variability in tracer transport in the upper troposphere and lower stratosphere is limited until current theories of gravity wave breaking have been refined.

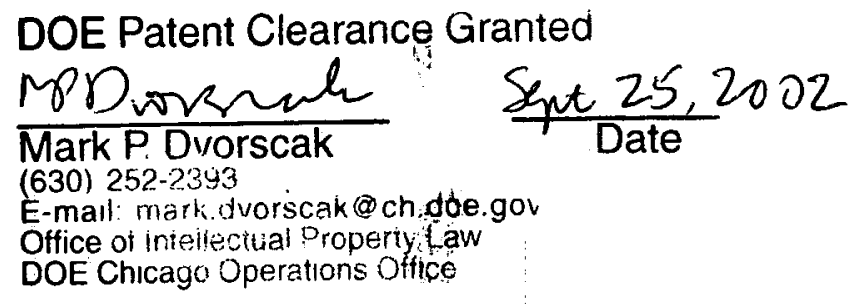




\section{DISCLAIMER}

This report was prepared as an account of work sponsored by an agency of the United States Government. Neither the United States Government nor any agency thereof, nor any of their employees, makes any warranty, express or implied, or assumes any legal liability or responsibility for the accuracy, completeness, or usefulness of any information, apparatus, product, or process disclosed, or represents that its use would not infringe privately owned rights. Reference herein to any specific commercial product, process, or service by trade name, trademark, manufacturer, or otherwise does not necessarily constitute or imply its endorsement, recommendation, or favoring by the United States Government or any agency thereof. The views and opinions of authors expressed herein do not necessarily state or reflect those of the United States Government or any agency thereof. 


\section{DISCLAIMER}

Portions of this document may be illegible in electronic image products. Images are produced from the best available original document. 
Publications supported by the project:

Jones, D. B. A., H. R. Schneider, and M. B. McElroy: Effects of the Quasi-Biennial Oscillation on the zonally averaged transport of tracers, J. Geophys. Res., 103, 11,235-11,249, 1998

Kogan, L.: An analysis of the propagation of seasonally varying tracer signals into the lower tropical stratosphere, Ph. D. thesis, Harvard University, 1999

Schneider, H. R., D. B. A. Jones, M. B. McElroy and G.-Y. Shi: Analysis of residual mean transport in the stratosphere. Part I: Model description and comparison with satellite data, J. Geophys. Res., 105, 19,991-20,011, 2000

Schneider, H. R., D. B. A. Jones, S. C. Wofsy, and M. B. McElroy: Analysis of residual mean transport in the stratosphere. Part II: Distributions of $\$ \mathrm{CO} 2 \$$ and the Mean Age of air.

J. Geophys. Res., 105, 20,013-20,024, 2000

Jones, D. B. A., A. E. Andrews, H. R. Schneider, and M. B. McElroy: Constraints on meridional transport in the stratosphere imposed by the mean age of air in the lower stratosphere, J. Geophys. Res., 106, $10,243-10,256,2001$ 